TABLE OF CONTENTS

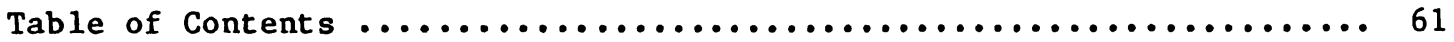

Editorial (I.S. Herschberg and H.J. van den Herik) .............. 61

Detection of Positional Patterns in Chess (I. Bratko, P. Tancig and

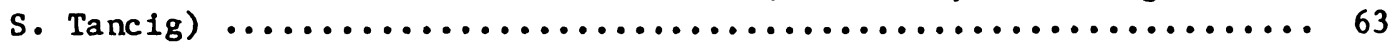

Computer Chess: Trick or Treat? (part III) (H.J. van den Herik and

J. de Jong-Gierveld) ................................. 74

Reviews (T.A. Marsland) ............................. 84

News, Information, Tournaments and Reports ................... 86

The Fourth Conference on Advances in Computer Chess (J.J. van

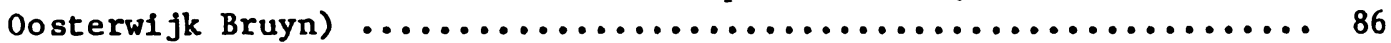

Korchnoi Defeats Nuchess in Half a Jiffy (H.J. van den Herik) ........ 94

International Computer-Chess Tournament in the Netherlands (J.J. van

0osterwijk Bruyn) $\ldots \ldots \ldots \ldots \ldots \ldots \ldots \ldots \ldots \ldots \ldots \ldots \ldots \ldots \ldots \ldots \ldots . \ldots \ldots \ldots$

Intermediate Fredkin Prize Awarded to Ken Thompson and Joe Condon

(The Fredkin Prize Committee) ...........................101

Cray Blitz versus David Levy (R.M. Hyatt) ....................... 102

Chess Master versus Computer (D.N.L. Levy) ..................... 106

The Last Rounds of Budapest .............................. 118

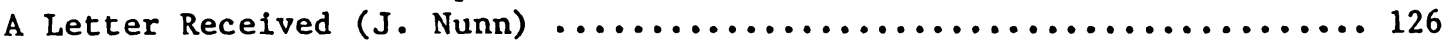

15th North American Computer-Chess Championship (San Francisco) ...... 128

4th World Microcomputer-Chess Championship (Glasgow) .............. 128

Chess on Non-standard Computer Architectures (Panel Discussion) ....... 129

How the Journal Reaches You ................................. 130

\title{
HITHER AND THITHER MOVES, AND MATES, AND SLAYS ... An Bditorial
}

The fortunes of computer chess seem to have dipped. As reported in this issue, Korchnol gave very short shrift to Nuchess. One might have let this ride: After all, the Vice-World Champion would predictably outshine his erstwhile programmed superior. The incident might have been written off by explaining that Nuchess was no more than a cock on a very small dunghill. However, this would be explaining it away. Tellingly, David Levy also did away with Cray Blitz, computer chess's current maestro.

To those not in the know, the defeats may seem to have been decisive, exemplary and paradigmatic. Computer programs should give up their pretensions: a tortoise cannot outrun a hare, mastery is to the human race, for now and forever, world without end ...

To the readers of our Journal, matters are not as simple they seem. True, David Levy, on his own admission, had not been active in chess for five years. It is tempting indeed to write him off as an opponent, had it not been for ... had it not been for his careful preparation for this match. This issue reveals that David had swotted up most conscientiously; not, it is true, by reading up master games, but by studying the ins and outs of chess as she was played by the program opposing him. Is it a real miracle then that David Levy overpowered his programmed opponent through meticulous study of its somewhat inflexible tactics?

Our answer is clearly in the negative. This victory does not point to a dip in the performance of programmed chess. More subtly, it points to an alerted master being ahead of one program. The dip some find in the pace of computer-chess development to us seems more apparent than real. It may we11 be 
argued - and we do so argue - that it is more due to the programmers' youthful exuberance than to any inherent long-term superiority of the victorious human opponents.

It is our fair conviction that no dip is showing in the best programs' performance. Many articles in this issue point to a slow but inexorable rise in their strength, continuing unabated for the last decade or so. Nor is there any reason for believing there will be a reversal of the slope in their rise. All one is willing to concede, editorially, is that the slope is not as steep as one might have wished and that the region of diminishing returns may be approaching. But this is mere opinion. Hans Berliner informally has proposed a test more decisive than any so far: Let a near-expert player (rated at some 2000 ELO points) be coached for a week in his opponent's mysteries. Then let them slog it out. If the coachee wins, computer chess should cut its losses and vanish from the scene like the fata morgana some take it for.

Or should it? To require abandoning it because of such a defeat would be very like abandoning psychology because 'my aunt had no visible benefits from her therapist'. It would be even more like the proverbial throwing out of the baby with the bath water.

Is not research into human achievements its own reward? Is not man the proper study of mankind? And should not our researchers be proud of even now outdoing all but a fraction of one percent of the world's chess-playing inhabitant s?

Bob Herschberg and Jaap van den Herik

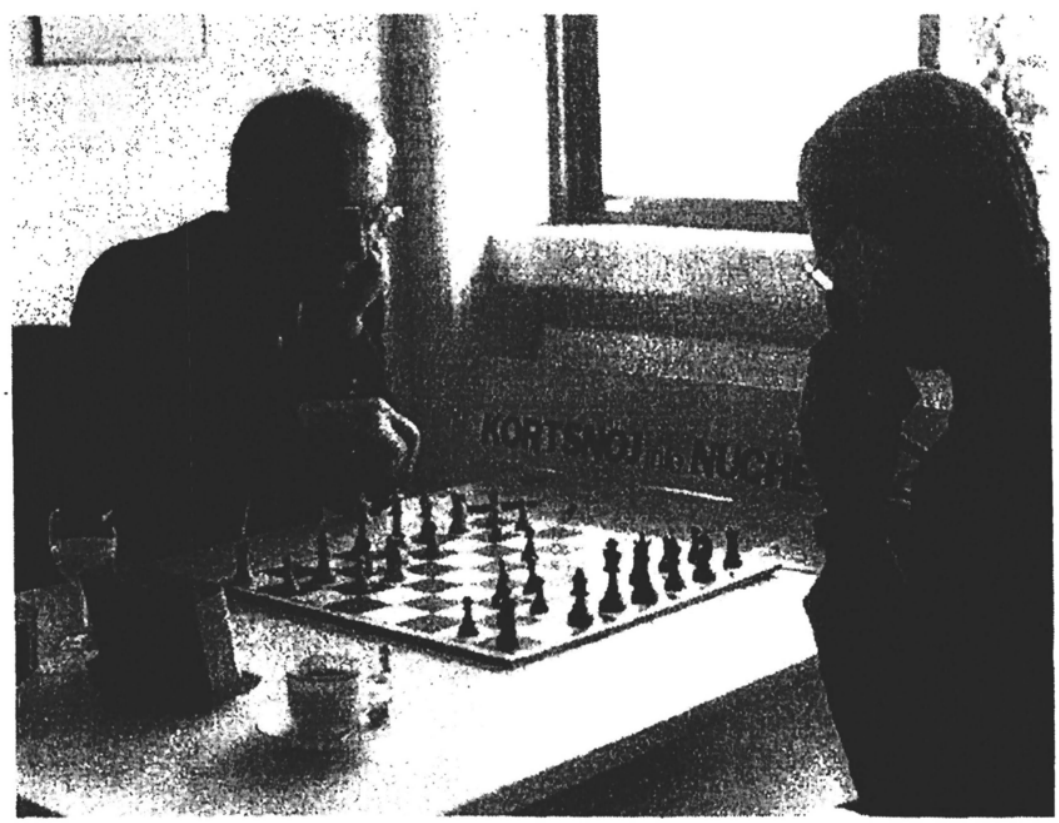

Photo by Louisa Lombardy

Giving short shrift 